\title{
Maternal adipose tissue response to nicotine administration in the pregnant rat: effects on fetal body fat and cellularity
}

\author{
BY CHRISTINE M. WILLIAMS AND TAZEEN KANAGASABAI \\ Department of Biological Sciences, North East Surrey College of Technology, \\ Reigate Road, Ewell, Surrey KT17 3DS
}

(Received 16 August 1982 - Accepted 12 April 1983)

1. Nicotine has been implicated as a causative factor in the intrauterine growth retardation associated with smoking in pregnancy. A study was set up to ascertain the effect of nicotine on fetal growth and whether this could be related to the actions of this drug on maternal adipose tissue metabolism.

2. Sprague-Dawley rats were mated and assigned to control and nicotine groups, the latter receiving nicotine in the drinking-water throughout pregnancy. Animals were weighed at regular intervals and killed on day 20 of pregnancy. Rates of maternal adipose tissue lipolysis and lipogenesis were measured. Fetal and placental weights were recorded and analysis of fetal body water, fat, protein and DNA carried out.

3. Weight gains of mothers in the nicotine group were less in the 1st and 2nd weeks of pregnancy, but similar to controls in the 3rd week. Fetal body-weights, DNA, protein and percentage water contents were similar in both groups. Mean fetal body fat $(\mathrm{g} / \mathrm{kg})$ was significantly higher in the nicotine group $(96 \cdot 2(\mathrm{se} 5 \cdot 1))$ compared with controls (72.0 (SE 2.9)). Rates of maternal lipolysis were also higher in the nicotine group.

4. The cause of these differences and their effects on maternal and fetal well-being is discussed.

Maternal smoking in pregnancy has been associated with low birth weights (Simpson, 1957; Savel \& Roth, 1962; Underwood et al. 1965; Landesman-Dwyer \& Emanuel, 1979), increased embryonic and fetal mortality (Meyer \& Tonascia, 1977), prematurity (Frazier et al. 1961) and increased incidence of congenital abnormalities (Naeye, 1978). Nicotine has been implicated as the causative agent in many of these disturbances. In pregnant rats, nicotine administration causes delayed blastocyte implantation (Yoshinaga et al. 1979), reduced embryo growth and retardation of parturition (Hammer \& Mitchell, 1979). An effect of nicotine on birth weight, however, has not been clearly established. At levels of administration equivalent to those found in smokers, Becker et al. (1968) found no significant retardation of fetal growth, although at higher dose levels maternal appetite, weight gain and birth weight were all significantly reduced.

There are a number of mechanisms by which nicotine could impair fetal growth. It may act to decrease maternal appetite (Becker \& King, 1966), it may interfere with fetal blood supply by its vasoconstrictive effects on uterine blood flow (Bruce, 1979) or it may cause alterations in fetal and maternal metabolism.

Previous investigations of normal metabolism during rat, guinea-pig and human pregnancies have established pronounced alterations in maternal adipose tissue function. These changes are believed to be directed towards the maintenance of fetal growth, particularly in late gestation (Knopp et al. 1970; Coltart \& Williams, 1976; Jones, 1976). Since nicotine and smoking are known to produce disturbances in adipose tissue metabolism (Hershbaum et al. 1961; Bizzi et al. 1972), it is possible that some of the harmful effects of nicotine in pregnancy may be attributed to its actions on this tissue.

In the present study we have investigated the effect of nicotine administration during pregnancy on weights at term and body composition of offspring. Rates of lipogenesis and lipolysis in maternal adipose tissue at term have also been studied. 
EXPERIM E NT A L

\section{Animals, diet and nicotine administration}

Sprague-Dawley female rats $(250-300 \mathrm{~g})$ were used in the present investigation and were fed on a stock diet (Labsure CRN; Labsure Ltd, Poole, Dorset) throughout the experiment. All animals received food and water ad lib. Nicotine was administered to the animals as nicotine tartrate in the drinking-water $(120 \mathrm{mg} / 1)$. Volumes of nicotine consumed were recorded by daily weighing of the water-bottles. The mean (with SE) daily intake of the nicotine group was calculated to be $2.46(0 \cdot 18) \mathrm{mg} / \mathrm{kg}$ per d. Previous work has shown this to be a suitable route of administration in rats (Krous et al. 1981), achieving blood profiles similar to those found in habitual smokers (Isaac \& Rand, 1972; Turner, 1975).

\section{Mating and killing of animals}

Animals were mated singly overnight and were randomly assigned to control and experimental (nicotine) groups the following morning (day 0 ). The occurrence of mating was assessed by checking for mating plugs. Animals were weighed at twice weekly intervals and weekly gains noted. On day 10 of pregnancy, animals were palpated and weighed. Any animals not found to be pregnant at this stage were killed and an autopsy carried out to check for evidence of resorption. Food intakes of the remaining pregnant animals were monitored from day 10 to day 20 of pregnancy; mean (with SE) daily intakes were found to be similar in both groups $(25.6(1.72) \mathrm{g} / \mathrm{d}$ in controls, $23.96(1.32) \mathrm{g} / \mathrm{d}$ in the nicotine group). Animals were killed on the morning of day 20 of pregnancy by a single blow to the head. Fetuses and placentas were removed, weighed and stored at $-20^{\circ}$ for subsequent analysis. Fetal abnormalities and numbers of resorption sites were noted. Perigenital adipose tissue was removed from seven animals in each group for the in vitro analysis of lipolysis and lipogenesis.

\section{Analytical methods}

Adipose tissue lipolysis. Lipolysis was measured by assaying the release of glycerol from small pieces of adipose tissue incubated in vitro. Pieces of tissue (approximately $100 \mathrm{mg}$ ) were incubated in glucose-free Krebs bicarbonate buffer, containing bovine serum albumin (fatty-acid free; $10 \mathrm{~g} / \mathrm{kg}$ ), at $37^{\circ}$ for $1 \mathrm{~h}$ in a shaking water-bath. Tissue was incubated under basal (buffer only) and stimulated $\left(10^{-4} \mathrm{M}\right.$-isoprenaline and $10^{-3} \mathrm{M}$-caffeine) conditions. Previous work had shown these concentrations to be suitable for maximal rates of lipolysis in similarly-incubated tissues. Following incubation, the tissue was removed and weighed. Incubation media were stored at $-20^{\circ}$ for the later analysis of glycerol. Glycerol was analysed by an enzymic, semi-automated technique (McCrae, 1974).

Adipose tissue lipogenesis. Adipose tissue pieces $(20-50 \mathrm{mg})$ were incubated with D[U-14 C]glucose and rates of incorporation into tissue triglycerides measured as described by Galton \& Wilson (1970).

Body composition. Body composition analyses were carried out on pooled offspring from single litters. For determination of body water, animals were weighed and dried in an oven at $90^{\circ}$ until no further weight loss was recorded. The dried carcasses were ground using a pestle and mortar before Soxhlet extraction with diethyl ether for the determination of body fat. The dried defatted carcasses were finely ground and samples taken for the analysis of DNA (Curtis-Prior et al. 1975) and protein (Gornall et al. 1949).

Statistical analysis of differences between means was carried out by the use of the unpaired $t$ test (Snedecor \& Cochran, 1980). 
Table 1. Weight gains of control and nicotine-treated pregnant rats*

(Mean values with their standard errors for groups of twelve rats)

\begin{tabular}{|c|c|c|c|c|c|c|c|c|}
\hline \multirow{3}{*}{$\begin{array}{l}\text { Week of } \\
\text { pregnancy... } \\
\text { Group }\end{array}$} & \multicolumn{8}{|c|}{ Wt gain $(\mathrm{g})$} \\
\hline & \multicolumn{2}{|l|}{1} & \multicolumn{2}{|c|}{2} & \multicolumn{2}{|c|}{3} & \multicolumn{2}{|c|}{ Total wt gain } \\
\hline & Mean & SE & Mean & SE & Mean & $\mathrm{SE}$ & Mean & $\mathrm{SE}$ \\
\hline Control & $26 \cdot 6$ & 1.6 & $31 \cdot 6$ & $1 \cdot 33$ & $77 \cdot 3$ & $3 \cdot 8$ & $135 \cdot 2$ & 5.6 \\
\hline Nicotine & $11 \cdot 6^{* * *}$ & $2 \cdot 5$ & $23 \cdot 5^{*}$ & $3 \cdot 1$ & $69 \cdot 3 \mathrm{NS}$ & $3 \cdot 2$ & $104 \cdot 5^{* * *}$ & 5.5 \\
\hline
\end{tabular}

NS, not significant $(P<0.05)$.

Mean values were significantly different from control values: ${ }^{*} P<0.05,{ }^{* * *} P<0.001$.

* For details of treatments, see p. 8.

Table 2. Fetal weights, DNA and protein contents, placental weights and litter sizes in control and nicotine-treated pregnant rats*

(Mean values with their standard errors for groups of twelve rats)

\begin{tabular}{|c|c|c|c|c|c|c|c|c|c|}
\hline \multicolumn{2}{|c|}{$\begin{array}{l}\text { Fetal } \\
\text { wt (g) }\end{array}$} & \multicolumn{2}{|c|}{$\begin{array}{c}\text { Fetal } \\
\text { DNA (mg) }\end{array}$} & \multicolumn{2}{|c|}{$\begin{array}{c}\text { Fetal } \\
\text { protein } \\
\text { (g/kg dry wt) }\end{array}$} & \multicolumn{2}{|c|}{$\begin{array}{l}\text { Placental } \\
\text { wt (g) }\end{array}$} & \multicolumn{2}{|c|}{$\begin{array}{l}\text { Litter } \\
\text { size }\end{array}$} \\
\hline Mean & $\mathrm{SE}$ & Mean & $\mathrm{SE}$ & Mean & $\mathrm{SE}$ & Mean & SE & Mean & SE \\
\hline \multicolumn{10}{|c|}{ Control } \\
\hline 3.90 & 0.12 & $17 \cdot 56$ & 1.05 & $\begin{array}{l}75 \cdot 36 \\
\text { Nicotine }\end{array}$ & $2 \cdot 83$ & 0.53 & 0.03 & 12.00 & 0.75 \\
\hline $4 \cdot 08 \mathrm{NS}$ & $0 \cdot 20$ & $17 \cdot 66 \mathrm{NS}$ & 1.55 & $75 \cdot 75 \mathrm{NS}$ & $4 \cdot 20$ & $0.55 \mathrm{NS}$ & $0 \cdot 02$ & $9 \cdot 80 \mathrm{NS}$ & 0.75 \\
\hline
\end{tabular}

NS, not significant $(P<0 \cdot 05)$.

* For details of treatments, see p. 8 .

\section{RESULTS \\ Maternal weight gains}

Table 1 shows the weekly weight gains of animals in the control and nicotine groups and the total weight gains throughout pregnancy. In the 1st week of pregnancy, the nicotine group gained significantly less weight than the control animals; in some cases nicotine animals lost weight at this stage. Weight gains in the nicotine group were also reduced, compared with controls, during the 2nd week of pregnancy, although the difference was much less marked. In the 3rd and final week of pregnancy there was no significant difference in the weight gained by the two groups of animals. However, total weight gain remained significantly less in the nicotine group.

Fetal weights, DNA and protein contents, placental weights and litter sizes

Table 2 shows no effect of nicotine administration in pregnancy on fetal growth. This is evident from the similar values obtained for fetal body-weight, DNA and protein in the two groups. It was clear that neither cell number nor cell size were reduced in the nicotine animals. Protein:DNA values calculated for the nicotine and control groups were (mean with SE) $19.75(1.06)$ and $18.80(1.60)$ respectively. Examination of the number of pups in each litter suggested a possible effect of nicotine in reducing litter size, but this difference was not shown to be statistically significant $(P>0.5)$. 
Table 3. Percentage body water and fat in fetuses of control and nicotine-treated pregnant rats*

(Mean values with their standard errors for groups of twelve rats)

\begin{tabular}{llcccc}
\hline & \multicolumn{2}{c}{ Percentage body water } & & \multicolumn{2}{c}{ Body fat (mg/fetus) } \\
\cline { 2 - 3 } \cline { 5 - 6 } Group & Mean & SE & & Mean & SE \\
\hline Control & 89.50 & 0.34 & & $29 \cdot 21$ & 1.84 \\
Nicotine & $89.30 \mathrm{NS}$ & 0.34 & & $43.98^{* *}$ & $4 \cdot 27$ \\
\hline
\end{tabular}

NS, not significant $(P>0.05)$.

Mean values were significantly different from control values: ${ }^{* *} P<0.01$.

* For details of treatment, see p. 8.

Table 4. Rates of in vitro lipogenesis and lipolysis in adipose tissue from control and nicotine-treated pregnant rats*

(Mean values with their standard errors for groups of seven rats)

\begin{tabular}{|c|c|c|c|c|c|c|}
\hline \multirow[b]{3}{*}{ Group } & \multirow{2}{*}{\multicolumn{2}{|c|}{$\begin{array}{c}\text { Lipogenesis } \\
(\mu \mathrm{mol} \text { glucose/g wet wt } \\
\text { tissue per } \mathrm{h})\end{array}$}} & \multicolumn{4}{|c|}{$\begin{array}{c}\text { Lipolysis } \\
(\mu \mathrm{mol} \text { glycerol released } / \mathrm{g} \text { wet } \mathrm{wt} \\
\text { tissue per } \mathrm{h})\end{array}$} \\
\hline & & & \multicolumn{2}{|c|}{ Basal } & \multicolumn{2}{|c|}{ Stimulated } \\
\hline & Mean & SE & Mean & $\mathbf{S E}$ & Mean & S.E. \\
\hline Control & $1 \cdot 15$ & 0.09 & 0.66 & 0.07 & 1.82 & 0.12 \\
\hline Nicotine & $i \cdot 17 \mathrm{NS}$ & 0.17 & $1 \cdot 12^{* *}$ & 0.09 & $2 \cdot 42^{*}$ & 0.25 \\
\hline
\end{tabular}

NS, not significant $(P<0 \cdot 05)$.

Mean values were significantly different from control values: ${ }^{*} P<0.05,{ }^{* *} P<0.01$.

* For details of treatment, see p. 8.

\section{Percentage body water and fat content}

The mean values for percentage body water and fat content are shown in Table 3 . Values for body water were identical in the two groups. Body fat content was, however, significantly higher in the nicotine group. The higher fat content of offspring from nicotine-treated mothers did not appear to be related to an effect of litter size, since regression analysis showed body fat content and body-weight to be independent of the number of offspring in each litter.

\section{Maternal adipose tissue lipogenesis and lipolysis}

Rates of lipogenesis and lipolysis in maternal adipose tissue are shown in Table 4 . There was no significant difference in lipogenic activity of tissue from the two groups of animals. Tissue from nicotine-treated animals did, however, show elevated rates of both basal and stimulated lipolysis. Under basal condition, glycerol release from adipose tissue was $65 \%$ higher in the nicotine-treated animals. This difference was also seen when tissue was incubated under conditions of maximal stimulation, where nicotine-treated animals showed a $30 \%$ higher rate of in vitro lipolysis.

\section{DISCUSSION}

In the present study, impaired maternal weight gains of nicotine-treated pregnant rats were not accompanied by corresponding reductions in body-weights or cellularity of offspring. 
These findings lend support to the view that nicotine is not a major factor in the fetal growth retardation associated with smoking in pregnancy. Haworth \& Ford (1972) showed that exposure of pregnant rats to tobacco smoke resulted in reduced body-weight and DNA and protein contents of offspring. Since previous investigations had shown no effect of nicotine or carbon monoxide (Younoszai et al. 1969), Haworth \& Ford (1972) attributed these findings to an 'unidentified component of tobacco smoke'. It is clear that adverse effects of nicotine on body-weights of offspring reported by previous authors may be attributable to the very high doses used (Becker et al. 1968; Hudson \& Timiras, 1972). Marked behavioural changes and impaired maternal appetites were observed in these studies. The doses employed in the present study were comparable with those of a $60 \mathrm{~kg}$ woman smoking twenty cigarettes daily. No adverse behavioural changes were observed and food intakes were similar in both groups of animals.

The effects of nicotine on maternal weight gain were seen to be most marked during the 1st week of pregnancy, when fetal growth is low but maternal weight gain is accelerated. Much of the weight gain observed during this period is attributed to increased lipid deposition in maternal adipose tissue (Fain \& Scow, 1966; Smith, 1973). In rat and human pregnancies, total body fat and fat cell size are increased during this early anabolic phase (Beaton et al. 1954; Pipe et al. 1979). Since nicotine is known to cause depletion of body fat in the rat (Thiennes \& Behrend, 1933), it seems likely that the retarded weight gains of the nicotine-treated mothers in early pregnancy represents a failure of this normal fat deposition.

It is well established in rat, guinea-pig and human pregnancies that late gestation represents a period of increased catabolism in the maternal system. Adipose tissue lipolysis and sensitivity to lipòlytic agents are increased (Knopp et al. 1970; Elliott, 1975; Coltart \& Williams, 1976; Jones, 1976) and fasting produces greater increases in plasma fatty acid and ketone levels and greater falls in blood glucose (Herrera et al. 1969; Felig \& Lynch, 1970). These changes are thought to be directed towards ensuring the maintenance of adequate fetal nutrition at the time of maximal growth rates (Knopp et al. 1973).

From the present investigation, it seems that nicotine enhances the catabolic state of adipose tissue at term, since both basal and stimulated lipolysis were higher in the nicotine-treated animals. The lipolytic actions of nicotine are believed to be due to increased catecholamine release from the adrenal medulla (Hershbaum et al. (1963). Since adipose tissue from pregnant animals shows greater sensitivity to the lipolytic actions of catecholamines (Knopp et al. 1970), the observed rates of lipolysis in nicotine-treated animals is most likely due to raised circulating levels of catecholamines. Rates of lipogenesis were shown to be similar in the two groups of animals; as lipolysis was shown to be raised in the nicotine-treated group, depletion of adipose tissue mass most likely occurred in these animals.

In the fetus, the effects of nicotine appear to be contrary to those observed in the mothers, since percentage body fat was higher in offspring of nicotine-treated mothers. It seems reasonable to propose that the increased adiposity recorded in the offspring from nicotine-treated mothers is directly due to increased release and transport of fatty acids from maternal adipose tissue to fetal circulation. This is despite evidence of poor permeability to fatty acids reported in the rat (Koren \& Shafrir, 1964). In other species, including man and guinea-pig, the placenta appears to be much more permeable to fatty acids (Szabo et al. 1969; Szabo \& Grimaldi, 1970). In vitro studies of human placentas have demonstrated that the maternal-fetal concentration gradient is the major factor determining the rate of transport of fatty acids (Booth et al. 1981). It seems probable that any factor causing elevation of maternal plasma fatty acids will lead to increased placental transport and greater fetal adiposity. This has been demonstrated in the rabbit where maternal starvation 
was shown to cause increased transport and deposition of fatty acids in fetal tissues (Elphick et al. 1978). It is tempting to speculate that in species showing greater placental permeability to fatty acids than the rat, the lipolytic actions of nicotine are likely to produce more pronounced effects on fetal adiposity than those observed here.

It may be concluded from the present investigation that the intra-uterine growth retardation associated with smoking in pregnancy may not be due to the actions of nicotine. Rather, this drug, by its lipolytic actions on the maternal system, leads to greater fat deposition in the fetus. It cannot, however, be concluded that the observed actions of nicotine are harmless to the mother or the developing fetus. By its actions in increasing lipolysis and raising maternal fatty acid levels, it may exacerbate the ketosis of short-term fasting observed in pregnant animals and man. This may be deterimental to offspring since ketone acids are taken up by the fetus and may replace glucose as an energy-yielding substance, particularly in the brain (Dahlquist et al. 1972). Frequent ketonuria in pregnancy is regarded as a risk factor, since there is evidence of impaired intellectual and psychological development in offspring of ketotic diabetic and nondiabetic mothers (Churchill \& Berendes, 1969; Churchill et al. 1969). The effects of nicotine on fetal adiposity may also be harmful since, if birth weight alone is used as an assessment of intra-uterine growth, greater adiposity may mask growth retardation produced by other components of cigarette smoke. By reducing early-pregnancy fat deposition in the mother, nicotine may reduce the capacity of the nursing mother to meet the energy demands of lactation, particularly when dietary intake is restricted. It would appear that the actions of nicotine in pregnancy may have important nutritional consequences, both to the offspring and mother. These effects warrant further investigation.

\section{REFERENCES}

Beaton, G. H., Beare, J., Ryu, M. H. \& McHenry, E. W. (1954). Journal of Nutrition 54,291-304.

Becker, R. F. \& King, J. E. (1966). American Journal of Obstetrics and Gynecology 95, 515-523.

Becker, R. F., Little C. R. D. \& King, J. E. (1968). American Journal of Obstetrics and Gynecology 100, $957-968$.

Bizzi, A., Tacconi, T., Medea, A. \& Garattini, S. (1972). Pharmacology 7, 216-223.

Booth, C., Elphick, M. C., Hendrickse, W. \& Hull, D. (1981). Journal of Developmental Physiology 3(3), $177-189$. Bruce, N. (1979). Biology of Reproduction 20, 229-233.

Churchill, J. A. \& Berendes, H. W. (1969). In Perinatal Factors Affecting Human Development PAHO Sci. Publ. no. 185. Washington DC: Pan American Health Organization.

Churchill, J. A., Berendes, H. W. \& Nemore, J. (1969). American Journal of Obstetrics and Gynecology 105, $257-268$.

Coltart, T. M. \& Williams, C. (1976). British Journal of Obstetrics and Gynaecology 83, 241-245.

Curtis-Prior, P. B., Handley, T. \& Temple, N. J. (1975). Analyst, London 100, 106-110.

Dahlquist, G., Persson, U. \& Persson, B. (1972). Biology of the Neonate 20, 40-50.

Edson, J. L., Hudson, D. G. \& Hull, D. (1975). Biology of the Neonate 27, 50-55.

Elliot, J. A. (1975). European Journal of Clinical Investigation 5, 159-163.

Elphick, M. C., Edson, J. L. \& Hull, D. (1978). Biology of the Neonate 34, 146-149.

Fain, J. N. \& Scow, R. O. (1966). American Journal of Physiology 210, 19-25.

Felig, P. \& Lynch, V. (1970). Science 170, 990-992.

Frazier, T. M., Davis, G. H., Goldstein, H. \& Goldberg, I. D. (1961). American Journal of Obstetrics and Gynecology 81, 988-996.

Galton, D. J. \& Wilson, J. D. D. (1970). Clinical Science 38, 66I-675.

Gornall, A. G., Bardawill, C. J. \& David, M. M. (1949). Journal of Biological Chemistry 177, $551-553$.

Hammer, R. E. \& Mitchell, H. E. (1979). Proceedings of the Society for Experimental Biology and Medicine 162, 333-336.

Haworth, J. C. \& Ford, J. D. (1972). American Journal of Obstetrics and Gynecology 112, 653-658.

Herrera, E., Knopp, R. H. \& Freinkel, N. (1969). Journal of Clinical Investigation 48, $2260-2272$.

Hershbaum, A., Bellet, S., Dickstein, E. R. \& Feinberg, L. J. (1961). Circulation Research 9, 631-638.

Hershbaum, A., Khorsandian, R., Caplan, R. F., Bellet, S. \& Feinberg, L. J. (1963). Circulation 28, 52-59.

Hudson, C. B. \& Timiras, P. S. (1972). Biology of Reproduction 7, 247-253.

Isaac, P. F. \& Rand, M. J. (1972). Nature 236, 308-310.

Jones, C. T. (1976). Biochemical Journal 156, 357--365.

Knopp, R. H., Herrera, E. \& Freinkel, N. (1970). Journal of Clinical Investigation 49, 1438-1446.

Knopp, R. H., Saudek, C. H., Arky, R. A. \& O’Sullivan, J. B. (1973). Endocrinology 92, 984-988. 
Koren, Z. \& Shafrir, E. (1964). Proceedings of the Society for Experimental Biology and Medicine 116, 411-414.

Krous, H. F., Campbell, G. A., Fowler, M. W. \& Catron, A. C. (1981). American Journal of Obstetrics and Gynecology 140, 743-747.

Landesman-Dwyer, S. \& Emanuel, I. (1979). Teratology 19, 119-125.

McCrae, A. R. (1974). Studies of metabolism consequent upon acute ingestion of carbohydrates in primates. PhD Thesis, University of London.

Meyer, M. B. \& Tonascia, J. A. (1977). American Journal of Obstetrics and Gynecology 128, 494-502.

Naeye, R. L. (1978). American Journal of Pathology 90, 289-293.

Pipe, N. G., Smith, T. Halliday, D., Edmonds, C. J., Williams, C. \& Coltart, T. M. (1979). British Journal of Obstetrics and Gynaecology 86, 929-935.

Savel, L. E. \& Roth, E. (1962). Obstetrics and Gynecology 20, 313-317.

Simpson, W. J. (1957). American Journal of Obstetrics and Gynecology 73, 808-810.

Smith, R. W. (1973). Journal of Dairy Research 40, 353-360.

Snedecor, G. W. \& Cochran, W. G. (1980). Statistical Methods, 7th ed. Ames, Iowa: Iowa State University Press.

Szabo, A. J. \& Grimaldi, R. D. (1970). Advances in Metabolic Disorders 4, 185-228.

Szabo, A. J., Grimaldi, R. D. \& Jung, W. E. (1969). Metabolism, Clinical and Experimental 18, $406-411$.

Thiennes, C. H. \& Behrend, A. (1933). Journal of Pharmacology and Experimental Therapy 48, 317-321.

Turner, D. M. (1975). Xenobiotica 5, 553-561.

Underwood, P. B., Hester, L. L., Laffitte, T. \& Gregg, K. V. (1965). American Journal of Obstetrics and Gynecology 91, $270-278$.

Yoshinaga, K., Rice, C., Krenn, J. \& Price, R. L. (1979). Biology of Reproduction 20, 294-303.

Younoszai, M. K., Peloso, J. \& Haworth, J. C. (1969). American Journal of Obstetrics and Gynecology 104, $1207-1213$. 